\title{
OPPORTUNITIES AND TENSIONS IN NEW ZEALAND ORGANISATIONS: THE INDIVIDUAL AND THE ORGANISATION IN DEVELOPMENT
}

\author{
Jane Bryson \\ Victoria Management School \\ Victoria University of Wellington \\ Mary Mallon \\ Human Resource Management Department \\ Massey University \\ Kiri Merritt \\ Victoria Management School \\ Victoria University of Wellington
}

\begin{abstract}
This paper is the first step in a much larger project investigating the development of human capability for New Zealand workplaces. The paper reports the findings of a pilot case study conducted in a local manufacturing organisation that had a good reputation for initiatives in human capability development. The study explored the factors that helped and hindered individuals in developing skills and capabilities in the workplace. The findings showed that three key features of organisational infrastructure drove and shaped capability within this manufacturing organisation: self directed teams, a company skills matrix linked to pay, and a production and quality management system. The study is discussed in light of a selection of the literature on workplaces and capability development. The paper explores the interaction of individual and organisational factors in the development of human capability, particularly self-esteem and workplaces as learning environments.
\end{abstract}

\section{Introduction}

The optimal conditions for developing human capability in New Zealand organisations are of interest and relevance to academics, policy makers and practitioners alike. These conditions are the focus of a large research programme at Victoria and Massey Universities, the "Developing human capability" project. This paper reports the findings of a pilot case study for this project which explored institutional, organisational and individual influences on the development of human capability in a New Zealand workplace. The paper outlines key themes from the literature, the approach taken to the case study, its findings and their implications for the ongoing research programme and understandings of human capability in the workplace.

\section{The literature and capability}

Several strands of literature are relevant to the discussion of human capability development presented by this paper. These include definitions of capability; human resource management practices and their impact on capability development; and individual capability. Our discussion of the literature is, of necessity, selective but geared to illuminating the pilot case study.

The literature has defined and discussed the concept of capability in a variety of ways, ranging from notions of organisational capability, economic capability, through to individual human capability. Unfortunately these notions are usually discussed in ignorance of or isolation from each other and are apparent in discussions as diverse as the competitive advantage of nations (Porter, 1990), resource based views of the firm (Barney, 1991), the discussion of dynamic capabilities as essential to organisations (Collis, 1994; Eisenhardt \& Martin, 2000; Winter, 2003), and human capability perspectives from learning to performance (Brown \& McCartney, 2004). This has led to definitional overlaps that find capability variously portrayed as an outcome (a capable nation, an effective economy, a capable worker, an informed citizen); an output (productivity, performance), and an input (knowledge, competency, ability to perform).

For the purposes of this initial research we have settled on a working definition of capability as the sustained ability to perform. This definition applies equally well to institutional, organisational and individual perspectives of human capability. It allows investigation of the many things that contribute to capability, from HRM practices, skill development, employability, through to self-esteem, ability, and access to opportunities. And it allows thinking about human capability as both an outcome, output and input.

\section{HRM practices \& capability development}

A feature of the HRM literature has been the longrunning debate on how human resource management 
relates to organisational performance (Huselid 1995; Guest, 2002). The importance of training and development has long been at the centre of those debates. Guest (1997) argued that HRM practices can improve company performance by increasing employee skills and abilities as well as providing more opportunities for them to be utilised which will in turn improve commitment and motivation. Despite considerable literature about the organisational benefits of training and development training is still seen by some as cost rather than investment. However recent discussion about the workplace as a learning environment focuses less on offjob training or training as a discrete (and potentially costly) activity and more on the potential learning which is embedded in daily work practices.

Billett (2001) has explored workplaces as learning environments. He argues that engaging workers as participants and learners is important, and the quality of learning experiences can be seen in terms of workplace affordances - in particular the kinds of activities and guidance that individuals are able to access and the sequencing of experiences which can improve workplace performance. Hence Billett maintains that learning through work is interdependent between the individuals participation (influenced by personal goals and directions) and workplace affordances.

Further to this, Fuller \& Unwin (2004) in a number of case studies found that learning environments that offer employees diverse forms of participation foster learning at work. The authors as a result of their research developed an expansive versus restrictive continuum, a model for evaluating both the quality of a learning environment and the type of workforce development strategy an organization employs. The continuum reflects aspects within a workplace that act as either barriers or opportunities to learning at work. Key environmental factors that appeared characteristic of expansive participation involved:

- "Opportunities to engage in multiple and overlapping communities of practice in and beyond the workplace,

- Primary community of practice has shared 'participative memory' cultural inheritance of workforce development (and apprenticeship)

- Breadth: Access to learning fostered by crosscompany experiences

- Planned time off-the-job includes formal education and time for reflection

- Access to a range of qualifications including knowledge-based awards"

- (Fuller \& Unwin, 2004, p.134).

Expansive learning environments in the workplace were also indicative of a workplaces ability to provide for both personal and organizational development needs. Restrictive environments were much more limited in the opportunities and access they afford their employees and as a result personal development and organisational development were less aligned.

Organisations have adopted a series of ways to promote learning through their HRM practices. One notable strategy taken up by some New Zealand organisations has been the use of skill-based pay (Ryan, 1996; Guthrie 2001). Wisneski (1999) observes that the purpose of skillbased pay is to motivate employees to gain additional skills, competencies and knowledge that will increase both their personal satisfaction and value to the organisation. However, Murray \& Gerhart (1998) warn that adequate resources must be committed to training and ensuring timely, unbiased appraisals, complementary job design and production scheduling. If any one of these factors is missing then either employees will make no effort toward skill acquisition or there will be increases in pay without increases in productivity or quality. Similarly, Tropman (2001) cautions that if skills acquired by employees are not used or become obsolete there may be a loss of motivation.

There has also been much recent attention paid to teams in New Zealand organisations (Ryan, 1996; Perry, Davidson \& Hill, 1995). Internationally this attention has begun to look at the advantages and disadvantages of teams as a site for learning (Rainbird et al, 2004). However, despite the vastness of the team literature the optimal management and rewarding of teams is not straightforward, and is underpinned by the inevitable tension between individual capability and team capability.

\section{Individuals \& capability development}

How individuals engage with work and with education, their experience of the institutional structures and of organisational policies, shapes the development of their capability. For instance, in general, research evidence suggests that development is most readily available to those already skilled and credentialed. Individuals have different capabilities, different potential to develop their capabilities, and because of changing societal circumstances different access to opportunities.

Several strands of debate in the literature on individuals and capability are relevant to the pilot case study. For instance, much of the discussion on the connection between individual skill and work is salient to thinking about capability. A number of authors portray skill for work as having the three dimensions of technical, cognitive and behavioural (this last is also variously referred to as citizenship behaviour, or emotional intelligence, etc.) (Mounier, 2001; Goleman, 1998; Hunter \& Schmidt, 1996). Hunter, Schmidt, Rauschenberger and Jayne (2001) suggest that there are different theories of how these individual skills connect to job performance. One, the 'lay theory of performance' suggests that the dominant determinant of individual differences in performance is effort. Thus managers and staff who subscribe to this view believe that lesser performers are just lazy or poorly motivated. Another view, 'learning theory', suggests that individual differences in job performance are explained by intelligence or ability to learn. Managers and staff 
subscribing to this view believe that lesser performers are not bright enough.

However, in another strand of research, Gardner and Pierce (1998) report that organisational-based self-esteem is the strongest predictor of ratings of job performance and employee satisfaction. Because of this, they recommend that: organisations should provide employees with clear roles, and support for skills that contribute to effective performance; managers should create opportunities for employees to experience success and then help them make personal attributions for that success, and give employees timely, positive, encouraging messages; organisational structures should be such that they send signals of inherent trust in employees as competent, valuable, contributing individuals.

Hence investigation of developing human capability calls for a multi-level approach. At an organisational level, it requires investigation into the ways in which $H R$ practices can boost productivity as well as contribute to individual self-esteem and well-being. At an individual level it requires an exploration of the ways in which individuals engage with paid work, and their experience of both institutional structures and organizational policies in shaping their capability development. Both need to be set within the context of legal and organisation specific employment arrangements as well as in industry context.

\section{The Pilot Study}

The pilot study was conducted in a manufacturing organisation, which had a reputation for capability development (as indicated to the researchers by a trade union in the organisation) but was also facing an uncertain future. Semi-structured interviews and a focus group were drawn on to uncover individual experiences of developing skills and capabilities in the workplace (that is, factors that helped and hindered their development), while concurrently revealing organisational infrastructure, policies and practices in place to build capability development. The interview participants represented a vertical sample of factory staff and the focus group consisted of a team from the factory floor. The study also investigated HR policies and practices using both documentary data and interviews with key HR, Training, Management and union staff. Content analysis was then used to analyse the research data. The text of interview transcripts and supporting documentation was coded according to common emergent themes and variables.

The study found that three key features of organisational infrastructure drove and shaped capability within this manufacturing organisation. These were: self-directed teams; the company skills matrix; and a production and quality management system. Self-directed teams in the factory had led to capability development in a number of ways. They had fundamentally shaped job design, so that staff worked across and were skilled in a range of activities in the team. This was reported to help relieve the boredom of repetitious tasks, and give satisfaction with team achievements. It also forced team responsibility for production, for working together, and for any associated issues. The team concept was supported by extensive training in skills to help team members work effectively in the team environment. Incentives, mainly pay related, were attached to team performance but also to individual skill development.

The company had a skills matrix linked to pay which was central to the incentive system for capability development. The company paid individuals for skill, and teams for results. The skills matrix encouraged capability development by providing a structured framework of training/skill development to be completed in order to achieve each pay level. This ranged from basic company induction courses through to planning, budgeting, conflict resolution, etc. Skill levels were assessed and some courses were also linked to the National Qualifications Framework. Factory staff reported both formal 'classroom' style training and informal on-the-job development and 'buddy' systems.

A production and quality management system had been an integral initiative with the self-directed teams in this factory, and is also supported by skill development. Some staff had been trained as production and quality management facilitators in the teams and they also helped to encourage ongoing capability development in teams. Another feature of the manufacturing environment was the, at times, uncertain future of the factory and the redundancy and superannuation provisions which enabled the factory to maintain a stable skilled staff. This in combination with good pay levels, excellent investment in capability development, and a good working environment, created a very loyal workforce reflected in low staff turnover and long tenure.

\section{Issues with human capability development}

An interesting range of issues emerged in discussion of capability development with factory staff and managers. Most were positive, but a few raised potentially negative tensions. There was no doubt that the company was regarded as a good employer with excellent skill development opportunities and rewards. The key issues of interest were around optimal conditions for a) the development of capability, and b) the demonstration or expression of capability in the workplace.

\section{Development of capability}

Talking to individual workers about experiences of developing their own capability, it was clear that a key factor that enabled capability development was receiving regular and consistent individual encouragement to develop by managers, coordinators, facilitators, and other team members. Workers could impose artificial limits on their capability (e.g., commonly we heard people use age as an excuse not to develop, or lack of confidence and lack of belief in their ability or worthiness to develop) encouragement is vital to overcoming these barriers. A few workers may genuinely have had a desire not to develop further, or not at all. Common barriers to developing further were a mixture of time constraints and not wanting additional stress. Both of these were often 
created by juggling family or out of work demands and the pressure of skill development and possibly a more demanding job. Not wishing to develop at all was more complex and is an area we could only speculate on unreliably (through anecdotes of colleagues perceived of as 'lazier') as none of the people we spoke to fell into this category.

Comment was made of lessons learned about integrating new team members particularly if they were of a very different age/generation to other team members - thus being aware of the impact of individual characteristics that may require a different type of encouragement in order to develop capability.

This company was good at providing individual and organisational encouragement and support for development. Having someone regularly and consistently believe in your capability (and its potential to be developed) was perceived as important in building trust and capability in the workplace. Workers also noted the importance of skill development/training that was externally recognised and thus transferable to outside of work, and to other work, thus increasing ones employability. Some training/development gaps were noted by staff around literacy (which had previously been covered by the company but was no longer), and technology.

Organisationally, the skills matrix and skill based pay already mentioned as a feature, also incentivised and rewarded skill development. However, while this was an exceptionally powerful mechanism for encouraging skill development, it could create some tensions. In this incentive system individuals regarded the purpose of developing skill was to increase pay. For the organisation the purpose of developing skill was to increase capability in the workplace to be reflected in productivity and operation of the factory. The organisation used production and quality management, teams and team performance bonuses (pay for results) to encourage people to use their skills to increase team capability (which is reflected in team productivity). However staff reported that there were some issues with getting people to use their capability in the workplace.

\section{Expression of capability}

Capability is not just about the opportunity and encouragement to develop, it is also about the opportunity to demonstrate and use that capability. It was in this area that some possible tensions emerged for this company. These were in two forms - i) those who won't use or won't share their knowledge, skills, capability, and ii) those who wanted to use their capabilities but could not.

\section{The Organisation}

i) There were suggestions that a small number of staff developed their skills in order to get more pay but then chose not to utilise those skills in the workplace. Alternatively a small number who used good capability in the workplace but were unwilling (or didn't know how) to share that knowledge/capability with others. ii) Some staff reported experiencing a skills-ceiling and/or a job-ceiling. The skills-ceiling seemed to arise when one got to the top of the company skills matrix and was faced with the question of what now? Where to next with developing the developed?

The job-ceiling seemed to arise from the flat structure, which meant that although higher level skills may be developed there was no role in which they could be fully exercised. Related to this there seemed to be a small number of workers who were in roles supporting or on the periphery of teams who found themselves in an unspecified capability space - i.e., they were not part of the factory team/skills matrix area, nor were they part of management level development. Thus their development relied very much on their own initiative.

\section{Conclusions}

This pilot study provided an opportunity to look at human capability development in action from the perspective of the individual and the organisation. It shows that capability development involves a number of complex processes whereby both the individual and the organisation are continually negotiating a way forward. And it raises questions about assumptions in the literature.

\section{The individual}

Billet's (2001) idea that learning at work is in part dependant on individual engagement is supported, and extended, by this pilot study. The findings build on his ideas by unpicking the factors and processes that impact on individual engagement. In particular, they reveal the importance of organisational based self-esteem to the capability development equation. For instance, many reported the encouragement to develop, opportunity to experience achievement as essential. The study also leads one to recognise and question several pervasive assumptions embedded in the broader individual and organisational development literature. One assumption is that everyone should, or would, want to develop their capability and use it in the workplace; another is that everyone is able to develop their capability. Discussion of those who did not develop or did not use their development seemed to reveal an implicit use of the 'lay' theory of individual difference in performance lesser performers are lazy/less motivated (Hunter, Schmidt et al, 2001) - by colleagues and managers. Inability to develop or learn was not ever considered as a possibility in this organisation. However, some staff reported that they ceased development as they had other, more important, non-work priorities. Indeed it is seldom considered in the literature that something may be more important than work!

The workplace environment is of importance in the pursuit of human capability. Individuals do not operate in a vacuum, they are part of a system of structures, processes and people that are not always constant but rather change and evolve as necessary. The pilot study findings support Fuller \& Unwin's (2004) suggestions that workplace affordances have the power to shape the 
extent to which learning and development occurs through both their structure and the opportunities they create. In the pilot study the workplace affordances were heavily circumscribed by the team structures in the factory. These constrained what was seen as relevant development and reduced opportunities for those residing outside the team structure. As one would have predicted from the literature the skill based pay and matrices had a motivating effect on capability development, however, the study shows they are ultimately self-limiting. In this case low staff turnover, high levels of capability development encouraged by skill based pay, and job design that did not keep pace with the developing workforce capability, meant that eventually employees experienced a lack of opportunity to utilise existing or newly developed skills. They hit a job ceiling. Conversely, people outside of the team structure felt disadvantaged in terms of development opportunities. They hit a skills ceiling. The obvious conclusion is that HRM practices are not an end in themselves, they need to be monitored and updated before they become counter productive.

This study clearly shows the impact of both the individual and the organisation on the sustained ability to perform. The evidence from the study points to a need for further research into the extent to which organisational provisions and individual perceptions of capability development are in alignment. It also verifies the importance of a research design that seeks an analysis connecting understandings at institutional, organisational and individual levels to better understand the processes involved in the development of human capability within New Zealand organisations.

\section{References}

Barney, J. (1991). Firm resources and sustaining competitive advantage, Reading MA: AddisonWesley.

Billett, S. (2001). Learning through work: Workplace affordances and individual engagement. Journal of Workplace Learning, 13(5/6), 209-214.

Brown, R. and McCartney, S. (2004). The development of capability: the content of potential and the potential of content, Education \& Training, 46(1), 7-10.

Collis, D. (1994). How valuable are organisational capabilities?, Strategic Management Journal, 15, 143-152.

Coopersmith, S. (1967). The Antecedents of Selfesteem, San Francisco: Freeman \& Co.

Eisenhardt, K. \& Martin, J. (2000). Dynamic capabilities: what are they?, Strategic Management Journal, 21, 1105-1121.

Fuller, A. \& Unwin, L. (2004). Expansive learning environments: Integrating organizational and personal development. In H. Rainbird, A. Fuller \&
A. Munro (Eds), Workplace Learning in Context. London: Routledge.

Gardner, DG \& Pierce, JL. (1998). Self-esteem and self-efficacy within the organizational context: an empirical examination, Group \& Organization management, 23(1), 48-70.

Goleman, D. (1998). What makes a leader?, Harvard Business Review, 76(6), 93-102.

Guest, D. (1997). Human resource management and performance: a review and research agenda, International Journal of Human Resource Management, 8, 265-276.

Guest, D. (2002). Human resource management, corporate performance and employee wellbeing: Building the worker into HRM. The Journal of Industrial Relations, 44(3), 335-358.

Guthrie, J. (2001). High involvement, turnover, and productivity - Evidence from New Zealand. Academy of Management Journal, 44(1), 180-191.

Hunter, J and Schmidt, F. (1996). Intelligence and job performance: economic and social implications, Psychology, Public Policy and Law, 2, 447-472

Hunter, J., Schmidt, F., Rauschenberger, J. and Jayne, M. (2001). Intelligence, motivation and job performance, Chapter 11 in Cooper, C \& Locke , E., Industrial and Organisational Psychology: Linking theory with practice. Oxford: Blackwell.

Huselid, M. (1995). The impact of HRM practices on turnover, productivity and corporate financial performance. Academy of Management Journal. 38(3), 635-672

Mounier, A. (2001). The three logics of skills in French literature, BVET working paper for The changing nature of work - vocational education and training to enable individuals and communities to meet the challenges of the changing nature of work. Sydney, NSW

Murray, B. \& Gerhart, B. (1998). An empirical analysis of skill-based pay program and plant performance outcomes. Academy of Management Journal, 41(1), 68-79.

Perry, Davidson. and Hill, R. (1995). Reform at work Workplace change and the industrial order Auckland, N.Z: Longman Paul Ltd

Porter, M. (1990). The Competitive Advantage of Nations. London: Macmillan

Rainbird, H., Fuller, A. and Munro, A. (eds). (2004) Workplace Learning in Context. London: Routledge. 
Ryan, R. (1996). Workplace reform in N.Z - The state of play. Report prepared for Workplace New Zealand. New Zealand: Wellington.

Tropman, J.E. (2001). The compensation solution: How to develop an employee-driven rewards system. San Francisco: Jossey-Bass.

Winter, S.G. (2003). Understanding dynamic capabilities, Strategic Management Journal, 24, 991-995.

Wisneski, B. (1999). Competency based pay (Working Paper Series No. 1). Hamilton: Dept. of Strategic
Management \& Leadership, University of Waikato.

\section{Acknowledgement}

This research was made possible by funding from the New Zealand Foundation of Research, Science \& Technology for the Developing human capability: employment institutions, organisations and individuals project. We also thank the pilot study company for their openness. 